\title{
Reduction of Carbonyl Compounds to Their Corresponding Alcohols by (Nicotine)(tetrahydroborato)zinc Complex as a New Stable and Efficient Reducing Agent
}

\author{
DAVOOD SETAMDIDEH AND MOSTAFA RAFIGH
}

Department of Chemistry, Faculty of Sciences, Mahabad Branch, Islamic Azad University,
Mahabad, 59135-443, Iran
davood.setamdideh@gmail.com
d.setamdideh@iau-mahabad.ac.ir

Received 11 October 2011; Accepted 03 December 2011

\begin{abstract}
Nicotine)(tetrahydroborato)zinc complex, $\left[\mathrm{Zn}\left(\mathrm{BH}_{4}\right)_{2}(\mathrm{nic})\right]$, as a stable yellow solid, was prepared quantitatively by complexation of an equimolar amounts of zinc tetrahydroborate and Nicotine at room temperature. This reagent can easily reduce variety of carbonyl compounds such as aldehydes, ketones, acyloins and $\alpha$-diketones to their corresponding alcohols in good to excellent yields. Reduction reactions were performed in $\mathrm{CH}_{3} \mathrm{CN}$ at room temperature.
\end{abstract}

Key Words: Nicotine, $\mathrm{Zn}\left(\mathrm{BH}_{4}\right)_{2}$, Reduction, Carbonyl Compounds.

\section{Introduction}

The discoveries of sodium borohydride has provided an efficient route for the reduction of functionalized molecules and they are commonly used in organic laboratory nowadays. In spite of their efficiency and convenience, sodium borohydride being weak reducing agent only for aldehydes, ketones and acid chlorides. ${ }^{1}$ So, controlling the reducing power of this reagent has been one of the main interests for organic chemists in many years. In fact, advances in such a field have been realized such as variation of alkali-metal cation and metal cation in the hydride complex, e.g., $\mathrm{Li}\left[\mathrm{BH}_{4}\right],{ }^{2} \mathrm{~K}\left[\mathrm{BH}_{4}\right],{ }^{3} \mathrm{Ca}\left[\mathrm{BH}_{4}\right]_{2},{ }^{4} \mathrm{Cu}\left[\mathrm{BH}_{4}\right]_{2},{ }^{5} \mathrm{Zn}\left[\mathrm{BH}_{4}\right]_{2},{ }^{6}$ $\mathrm{Ti}\left[\mathrm{BH}_{4}\right]_{3},{ }^{7} \mathrm{Zr}\left[\mathrm{BH}_{4}\right]_{4}$ and the others; ${ }^{7 b}$ Zinc tetrahydroborate, $\mathrm{Zn}\left(\mathrm{BH}_{4}\right)_{2}$, as a nonconventional hydride transferring agent, has been reported to effect very efficient chemo-, regio- and stereoselective reductions in several compelex substrates. ${ }^{8 \mathrm{a}}$ This potential reducing agent is a neutral and can be used in a range of aprotic solvents such as ether, THF and DME. High coordination ability of zinc makes zinc tetrahydroborate more selective in its hydride transferring reactions. In spite of this, zinc tetrahydroborate has been used less than regular reducing agents in laboratory for the reduction of organic compounds, probably because of non-availability as a commercial reagent, being freshly prepared solution just prior to use and limitation to handling and storage. The reducing abilities of zinc tetrahydroborate have 
been reviewed. ${ }^{8 \mathrm{~b}}$ In addition to using zinc tetrahydroborate alone as a mild reducing agent, its combination systems e.g., $\mathrm{Zn}\left(\mathrm{BH}_{4}\right)_{2} / \mathrm{TMEDA}^{9},{ }^{9 \mathrm{a}} \mathrm{Zn}\left(\mathrm{BH}_{4}\right)_{2} / \mathrm{Me}_{3} \mathrm{SiCl}{ }^{9 b}$ and $\mathrm{Zn}\left(\mathrm{BH}_{4}\right)_{2} / \mathrm{TFA} / \mathrm{DME}^{9 \mathrm{c}}$ are of interest and have been used for different reduction purposes. Along the outlined strategies some modifications of zinctetrahydroborate such as poly[(tetrahydroborato)( $\eta$-pyrazine)zinc complex , $\left[\mathrm{Zn}\left(\mathrm{BH}_{4}\right)_{2}(\mathrm{pyz})\right] \mathrm{n},{ }^{10}$ (1,4-diazabicyclo[2.2.2] octane) (tetrahydroborato)zinc complex, $\left[\mathrm{Zn}\left(\mathrm{BH}_{4}\right)_{2}(\right.$ dabco $\left.)\right],{ }^{11}$ bis(tetrahydroborato) (triphenyl phosphine) zinc, $\left[\mathrm{Zn}\left(\mathrm{BH}_{4}\right)_{2}\left(\mathrm{Ph}_{3} \mathrm{P}\right)_{\mathrm{x}}\right](\mathrm{X}=1 \quad \& \quad 2),{ }^{12 \mathrm{a}}\left[\mathrm{Zn}\left(\mathrm{BH}_{4}\right)_{2}(\mathrm{bpy})\right]^{12 \mathrm{~b}}$, and $\left[\mathrm{Zn}\left(\mathrm{BH}_{4}\right)_{2}(\mathrm{nmi})\right]^{12 \mathrm{c}}$ have been made and used for reduction of organic compounds. In continuation of our interest for preparation of new modified tetrahydroborates, we now wish to report the preparation of new stable ligand-zinc tetrahydroborate such as (Nicotine)(tetrahydroborato)zinc complex, $\left[\mathrm{Zn}\left(\mathrm{BH}_{4}\right)_{2}(\mathrm{nic})\right]$ and its reducing ability in the reduction of carbonyl compounds such as aldehydes, ketones and acyloins, $\alpha$-diketones to their corresponding alcohols.

\section{Experimental}

All substrates and reagents were purchased from commercially sources with the best quality and used without further purification. IR and ${ }^{1} \mathrm{H}$ NMR spectra were recorded on PerkinElmer FT-IR RXI and $300 \mathrm{MHz}$ Bruker spectrometers, respectively. The products were characterized by their ${ }^{1} \mathrm{H}$ NMR or IR spectra and comparison with authentic samples (melting or boiling points). Organic layers were dried over anhydrous sodium sulfate. All yields referred to isolated pure products. TLC was applied for the purity determination of substrates, products and reaction monitoring over silica gel $60 \mathrm{~F}_{254}$ aluminum sheet.

Preparation of (Nicotine)(tetrahydroborato)zinc Complex; $\left[\mathrm{Zn}\left(\mathrm{BH}_{4}\right)_{2}(\right.$ nic)]

An ethereal solution of $\mathrm{Zn}\left(\mathrm{BH}_{4}\right)_{2}(0.16 \mathrm{M}, 250 \mathrm{~mL})$ was prepared from $\mathrm{ZnCl}_{2}(5.452 \mathrm{~g}, 0.04$ mol) and $\mathrm{NaBH}_{4}(3.177 \mathrm{~g}, 0.084 \mathrm{~mol})$ according to an available procedure in the literature [12c]. Then, nicotine $(6.48 \mathrm{~g}, 0.04 \mathrm{~mol})$ in ether $(50 \mathrm{~mL})$ was added dropwise to the ethereal solution of $\mathrm{Zn}\left(\mathrm{BH}_{4}\right)_{2}$ and stirred for $30 \mathrm{~min}$. Evaporation of the solvent under vacuum at room temperature gave $\left[\mathrm{Zn}\left(\mathrm{BH}_{4}\right)_{2}(\right.$ nic $\left.)\right]$ as a yellow powder in a quantitative yield $(9.16 \mathrm{~g}$, $95 \%$ ). which decomposes to dark material at $121-122^{\circ} \mathrm{C}$. Found: $\mathrm{Zn}: 24.83 \%$, B: $7.7 \%$. Calculated for $\mathrm{C}_{10} \mathrm{H}_{22} \mathrm{~N}_{2} \mathrm{~B}_{2} \mathrm{Zn}, \mathrm{Zn}: 25.41 \%$, B: $8.4 \%$.

Reduction of Benzaldehyde to Benzyl alcohol with [Zn(BH $\left.\left.{ }_{4}\right)_{2}(n i c)\right]$, A Typical Procedure

Table 1. Optimization Reaction Conditions of Reduction of Benzaldehyde with $\left[\mathrm{Zn}\left(\mathrm{BH}_{4}\right)_{2}(\mathrm{nic})\right]$ at Room Temperature

\begin{tabular}{lcccc}
\hline Entry & Molar ratio $^{\mathrm{a}}$ & Solvent & Time, min & Conversion $^{\mathrm{b}}, \%$ \\
\hline 1 & $(1: 0.5)$ & THF & 90 & 100 \\
2 & $(1: 0.5)$ & THF & 30 & 100 \\
3 & $(1: 1)$ & THF & 10 & 100 \\
4 & $(1: 1)$ & $\mathrm{CH}_{3} \mathrm{CN}$ & 5 & 100 \\
\hline
\end{tabular}

${ }^{\mathrm{a}}$ Molar ratio as Benzaldehyde: $\left[\mathrm{Zn}\left(\mathrm{BH}_{4}\right)_{2}(\mathrm{nic})\right],{ }^{\mathrm{b}} \mathrm{Completion}$ of the reaction was monitored by TLC (eluent, $\mathrm{CCl}_{4}, \mathrm{Et}_{2} \mathrm{O}: 5 / 2$ ).

In a round-bottomed flask $(10 \mathrm{~mL})$, equipped with a magnetic stirrer, a solution of banzaldehye $(0.106 \mathrm{~g}, 1 \mathrm{mmol})$ in $\mathrm{CH}_{3} \mathrm{CN}(3 \mathrm{~mL})$ was prepared. The complex reducing agent $(0.162 \mathrm{~g}, 1 \mathrm{mmol})$ was then added as a solid and the mixture was stirred at room temperature. TLC monitored the progress of the reaction (eluent; $\mathrm{CCl}_{4} / \mathrm{Et}_{2} \mathrm{O}: 5 / 2$ ). After completion of the reaction in $5 \mathrm{~min}$, a solution of $5 \% \mathrm{HCl}(5 \mathrm{~mL})$ was added to the reaction 
mixture and stirred for $10 \mathrm{~min}$. The mixture was extracted with $\mathrm{CH}_{2} \mathrm{Cl}_{2}(3 \times 10 \mathrm{~mL})$ and dried over the anhydrous sodium sulfate. Evaporation of the solvent and short column chromatography of the resulting crude material over silica gel by eluent of $\mathrm{CCl}_{4} / \mathrm{Et}_{2} \mathrm{O}: 5 / 2$ afforded the pure liquid benzyl alcohol $(0.101 \mathrm{~g}, 94 \%$ yield, table 1$)$

\section{Results and Discussion}

(Nicotine)(tetrahydroborato)zinc complex, $\left[\mathrm{Zn}\left(\mathrm{BH}_{4}\right)_{2}(\mathrm{nic})\right]$, is a stable yellow solid which can be readily prepared by complexation of $1: 1$ ethereal solution of zinc tetrahydroborate and nicotine at room temperature. The complex is readily formed quantitatively to give a yellow solid. Filtration and evaporation of the solvent result in a yellow fluffy powder which could be stored in a sealed bottle for months without losing its activity. The $\mathrm{Zn}$ content in the complex is determined by both gravimetric and atomic absorption techniques. The measurements data are in good agreement with the proposed structure of the reagent as $\left[\mathrm{Zn}\left(\mathrm{BH}_{4}\right)_{2}(\right.$ nic) $)$ (Figure 1).<smiles></smiles>

Figure 1. (Nicotine)(tetrahydroborate)zinc complex.

The solubility behavior of $\left[\mathrm{Zn}\left(\mathrm{BH}_{4}\right)_{2}(\mathrm{nic})\right]$ in various aprotic solvents such as $\mathrm{Et}_{2} \mathrm{O}, \mathrm{CH}_{2} \mathrm{Cl}_{2}$, $\mathrm{CHCl}_{3}, \mathrm{CH}_{3} \mathrm{CN}$ and THF was studied and observed that this reagent is slightly soluble in these solvents. $\left[\mathrm{Zn}\left(\mathrm{BH}_{4}\right)_{2}(\mathrm{nic})\right]$ in protic solvents such as methanol and ethanol is unstable and decomposed with the evolution of hydrogen gas. For the selection of appropriate solvent in reduction reactions, benzaldehyde and acetophenone as model compounds was adopted in $\mathrm{CH}_{3} \mathrm{CN}$ and THF. Our observation reveals that the reduction of carbonyl compounds in $\mathrm{CH}_{3} \mathrm{CN}$ provided a fast reaction rate and efficiency (Table 1, entry 4 \& Table 2, entry 3).

Table 2. Optimization Reaction Conditions of Reduction of Acetophenone with

\begin{tabular}{lcccc}
\multicolumn{5}{c}{$\left[\mathrm{Zn}\left(\mathrm{BH}_{4}\right)_{2}(\right.$ nic $\left.)\right]}$. \\
\hline Entry & Molar ratio $^{\mathrm{a}}$ & Solvent & Time, min & Conversion $^{\mathrm{b}}, \%$ \\
\hline 1 & $(1: 1)^{\mathrm{c}}$ & $\mathrm{CH}_{3} \mathrm{CN}$ & 120 & $<100$ \\
2 & $(1: 1)^{\mathrm{d}}$ & $\mathrm{CH}_{3} \mathrm{CN}$ & 110 & 100 \\
3 & $(1: 2)^{\mathrm{c}}$ & $\mathrm{CH}_{3} \mathrm{CN}$ & 80 & 100 \\
4 & $(1: 2)^{\mathrm{d}}$ & $\mathrm{CH}_{3} \mathrm{CN}$ & 15 & 100 \\
5 & $(1: 2)^{\mathrm{c}}$ & $\mathrm{THF}$ & 90 & 100 \\
6 & $(1: 2)^{\mathrm{d}}$ & $\mathrm{THF}$ & 25 & 100 \\
\hline
\end{tabular}

\footnotetext{
${ }^{a}$ Molar ratio as acetophenone:[ $\mathrm{Zn}\left(\mathrm{BH}_{4}\right)_{2}($ nic $\left.)\right]$.

${ }^{\mathrm{b}}$ Completion of the reaction was monitored by TLC (eluent, $\mathrm{CCl}_{4}, \mathrm{Et}_{2} \mathrm{O}: 5 / 2$ ).

${ }^{\mathrm{c}}$ Reaction carried out at room temperature.

${ }^{\mathrm{d}}$ reaction carried out under reflux condition.
} 
The required molar ratio of the reducing agent varies between 1-2 molar equivalents according to the nature of carbonyl group in a molecule. Transformation of aldehydes and ketones to their alcohols is one of the most important reactions in organic synthesis. $\mathrm{NaBH}_{4}$ is usually used for the reduction of aldehydes and ketones to their corresponding alcohols in protic solvents such as ethanol or isopropyl alcohol. This goal could be easily achieved by $\left[\mathrm{Zn}\left(\mathrm{BH}_{4}\right)_{2}(\mathrm{nic})\right]$ in aprotic solvents such as $\mathrm{CH}_{3} \mathrm{CN}$. Reduction of a variety of structurally different aromatic and aliphatic aldehydes to their corresponding alcohols is performed efficiently with this reducing agent (Table 3).

Table 3. Reduction of Aldehydes with $\left[\mathrm{Zn}\left(\mathrm{BH}_{4}\right)_{2}(\mathrm{nic})\right]$ at Room Temperature in $\mathrm{CH}_{3} \mathrm{CN}$.

\begin{tabular}{|c|c|c|c|c|c|}
\hline Entry & Substrate & Product & $\begin{array}{c}\text { Molar ratio } \\
\text { reagent/Substrat } \\
\mathrm{e}\end{array}$ & $\begin{array}{l}\text { Time, } \\
\text { min }\end{array}$ & $\begin{array}{c}\text { Yield }^{\mathrm{a}}, \\
\%\end{array}$ \\
\hline 1 & benzaldehyde & benzyl alcohol & $1: 1$ & 5 & 94 \\
\hline 2 & 4-chlorobenzaldehyde & 4-chlorobenzyl alcohol & $1: 1$ & 5 & 92 \\
\hline 3 & 3-chlorobenzaldehyde & 3-chlorobenzyl alcohol & $1: 1$ & 5 & 95 \\
\hline 4 & 2,4-dichlorobenzaldehyde & 2,4-dichlorobenzyl alcohol & $1: 1$ & 5 & 94 \\
\hline 5 & 4-methylbenzaldehyde & 4-methylbenzyl alcohol & $1: 1$ & 10 & 93 \\
\hline 6 & 4-methoxybenzaldehyde & 4-methoxybenzyl alcohol & $1: 1$ & 25 & 92 \\
\hline 7 & 4-hydroxybenzaldehyde & 4-hydroxybenzyl alcohol & $1: 1$ & 20 & 94 \\
\hline 8 & 2-hydroxybenzaldehyde & 2-hydroxybenzyl alcohol & $1: 1$ & 20 & 92 \\
\hline 9 & 3-nitrobenzaldehye & 3-nitrobenzyl alcohol & $1: 1$ & 2 & 90 \\
\hline 10 & 4-nitrobenzaldehyde & 4-nitrobenzyl alcohol & $1: 1$ & 2 & 97 \\
\hline 11 & 3-bromobenzaldehyde & 3-bromobenzyl alcohol & $1: 1$ & 2 & 98 \\
\hline 12 & $\begin{array}{l}\text { 4-hydroxy-3-methoxy } \\
\text { benzaldehyde }\end{array}$ & $\begin{array}{l}\text { 4-hydroxy-3- } \\
\text { methoxybenzyl alcohol }\end{array}$ & $1: 1$ & 25 & 95 \\
\hline 13 & Furfural & furfuryl alcohol & $1: 1$ & 2 & 89 \\
\hline 14 & 1-naphthaldehyde & 1-naphthyl methanol & $1: 1$ & 2 & 95 \\
\hline 15 & 2,6-dimethylhept-5-enal & 2,6-dimethylhept-5-en-1-ol & $1: 1$ & 2 & 90 \\
\hline 16 & heptanal & 1-heptanol & $1: 1$ & 2 & 83 \\
\hline
\end{tabular}

${ }^{\mathrm{a}}$ Yields refer to isolated pure products.

Aldehydes are reduced with 1 molar amounts of the reagent in $\mathrm{CH}_{3} \mathrm{CN}$ at room temperature in high to excellent yields (83-98\%). Reduction of ketones is also performed well with 2 molar amounts of the reagent at room temperature or reflux condition. The efficiency of these reactions were also excellent (84-98\%) (Table 4).

In order to show the efficiency of the reagent, we compared our results with those of reported in the literature for $\left[\mathrm{Zn}\left(\mathrm{BH}_{4}\right)_{2}(\mathrm{dabco})\right],{ }^{11}\left[\mathrm{Zn}\left(\mathrm{BH}_{4}\right)_{2}(\mathrm{pyz})\right] \mathrm{n},{ }^{12}\left[\mathrm{Zn}\left(\mathrm{BH}_{4}\right)_{2}\left(\mathrm{Ph}_{3} \mathrm{P}\right)\right],{ }^{12 \mathrm{a}}$ $\left[\mathrm{Zn}\left(\mathrm{BH}_{4}\right)_{2}\left(\mathrm{Ph}_{3} \mathrm{P}\right)_{2}\right],{ }^{12 \mathrm{~b}} \quad \mathrm{Zn}\left[\mathrm{BH}_{4}\right],{ }^{\mathrm{a},},{ }^{13} \quad\left[\mathrm{Zn}\left(\mathrm{BH}_{4}\right)_{2} \mathrm{XP}_{4}\right],{ }_{14} \mathrm{Ph}_{3} \mathrm{PMe}\left[\mathrm{BH}_{4}\right]$, $\left[\mathrm{PhCH}_{2}(\right.$ dabco $\left.)\right] \mathrm{BH}_{4},{ }^{16} \mathrm{Bu}_{4} \mathrm{~N}\left[\mathrm{BH}_{4}\right],{ }^{17}\left[\mathrm{Zn}\left(\mathrm{BH}_{4}\right)_{2}(\mathrm{bpy})\right]^{12 \mathrm{~b}}$, and $\left[\mathrm{Zn}\left(\mathrm{BH}_{4}\right)_{2}(\mathrm{nmi})\right]^{12 \mathrm{c}}$ (Table $5)$. 
Table 4. Reduction of Ketones with $[\mathrm{Zn}(\mathrm{BH} 4) 2(\mathrm{nic})]$ in $\mathrm{CH} 3 \mathrm{CN}$ at Room Temperature

\begin{tabular}{|c|c|c|c|c|c|}
\hline Entry & Substrate & Product & $\begin{array}{c}\text { Molar ratio } \\
\text { reagent/Substrate }\end{array}$ & $\begin{array}{l}\text { Time, } \\
\text { min }\end{array}$ & $\begin{array}{l}\text { Yield }^{\mathrm{a}}, \\
\%\end{array}$ \\
\hline 1 & benzophenone & diphenylmethanol & $2: 1$ & 165 & 96 \\
\hline 2 & acetophenone & 1-phenylethanol & $2: 1$ & 80 & 95 \\
\hline 3 & 4-bromo acetophenone & $\begin{array}{l}\text { 1-(4-brom } \\
\text { ophenyl)ethanone }\end{array}$ & $2: 1$ & 70 & 95 \\
\hline 4 & 4-methoxy acetophenone & $\begin{array}{c}\text { 1-(4-metho } \\
\text { xyaphenyl)ethanone }\end{array}$ & $2: 1$ & 130 & 98 \\
\hline 5 & 4-methyl acetophenone & $\begin{array}{c}\text { 1-(4-meth } \\
\text { ylphenyl)ethanone }\end{array}$ & $2: 1$ & 120 & 93 \\
\hline 6 & 4-methoxy benzaldehyde & $\begin{array}{l}\text { 1-(4-methoxy benzyl } \\
\text { alcohol }\end{array}$ & $2: 1$ & 240 & 94 \\
\hline 7 & 4-nitro acetophenone & $\begin{array}{c}\text { 1-(4-nitro } \\
\text { phenyl)ethanone }\end{array}$ & $2: 1$ & 40 & 92 \\
\hline 8 & 4-chloro acetophenone & $\begin{array}{c}\text { 1-(4-chloro } \\
\text { phenyl)ethanone }\end{array}$ & $2: 1$ & 75 & 95 \\
\hline 9 & 2,3-dihyro inden-1-one & $\begin{array}{l}\text { 2,3-dihydro-1H-inden- } \\
\text { 1-ol }\end{array}$ & $2 / 1$ & 200 & 95 \\
\hline 10 & 9H-fluoren-9-one & 9H-fluoren-9-ol & $2 / 1$ & 270 & 96 \\
\hline 11 & 2-methyl cyclohexanone & 2-methyl cyclohexanol & $2 / 1$ & 15 & 88 \\
\hline 12 & cyclohexanone & cyclohexanol & $2 / 1$ & 10 & 85 \\
\hline 13 & 4-phenyl cyclohexanone & 4-phenyl cyclohexanol & $2 / 1$ & 10 & 94 \\
\hline 14 & 3-pentan one & 3-pentanol & $2 / 1$ & 10 & 90 \\
\hline 15 & 4-methyl-2-entanone & 4-methyl-2-pentanol & $2 / 1$ & 10 & 84 \\
\hline
\end{tabular}

${ }^{\mathrm{a}}$ Yields refer to isolated pure products

Synthetic applications of $\alpha$-hydroxy ketones and $\alpha$-diketones are well known and their reductions to vicinal diols and/or acyloins are the subject of interests in organic synthesis. Reduction of $\alpha$-diketones usually gives a mixture of $\alpha$-hydroxy ketones and vicinal diols. In spite of this, some chemical or biochemical reagents can undergo selective reduction of $\alpha$ diketones to only one of the mentioned products. For example; $\mathrm{Zn} / \mathrm{H}_{2} \mathrm{SO}_{4}{ }^{18} \mathrm{TiCl}_{3}$ or $\mathrm{VCl}_{2} / \mathrm{THF}^{19}{ }^{19}\left(\mathrm{C}_{2} \mathrm{H}_{5} \mathrm{O}\right)_{3} \mathrm{P}^{20}{ }^{20} \mathrm{H}_{2} \mathrm{~S} /$ piperidine/DMF ${ }^{21}$ and heating with benzpinacol ${ }^{22}$ performed reduction of $\alpha$-diketones to acyloins. Reduction of $\alpha$-diketones with modified tetrahydroborate agents is also subject of the interest and easily achieved by $\left[\mathrm{Zn}\left(\mathrm{BH}_{4}\right)_{2}(\mathrm{nic})\right]$. This reagent with 2 molar equivalents efficiently reduces $\alpha$-diketones to their vicinal diols in $\mathrm{CH}_{3} \mathrm{CN}$ at room temperature (Table 6 , entry $1,3 \& 5$ ). Our attempts for reduction of $\alpha$ diketones to acyloins were unsatisfactory and only vicinal diols were detected as products (88-95\%). In addition to the reduction of acyloins to vicinal diols is also important in organic synthesis. For this transformation using $\mathrm{H}_{2} / \mathrm{CuCr}_{2} \mathrm{O}_{4},{ }^{23} \mathrm{Saccharomyces}$ cerevisiae (bakers yeast) ${ }^{24}$ and modified tetrahydroborate agents ${ }^{12 \mathrm{~b}}$ have been reported. In continuation of our study, this goal also easily achieved by $\left[\mathrm{Zn}\left(\mathrm{BH}_{4}\right)_{2}(\mathrm{nic})\right]$ efficiently at temperature in $\mathrm{CH}_{3} \mathrm{CN}$ by utilizing 2 molar equivalent of the reagent (Table 6 , entry $2 \& 4$ ). 


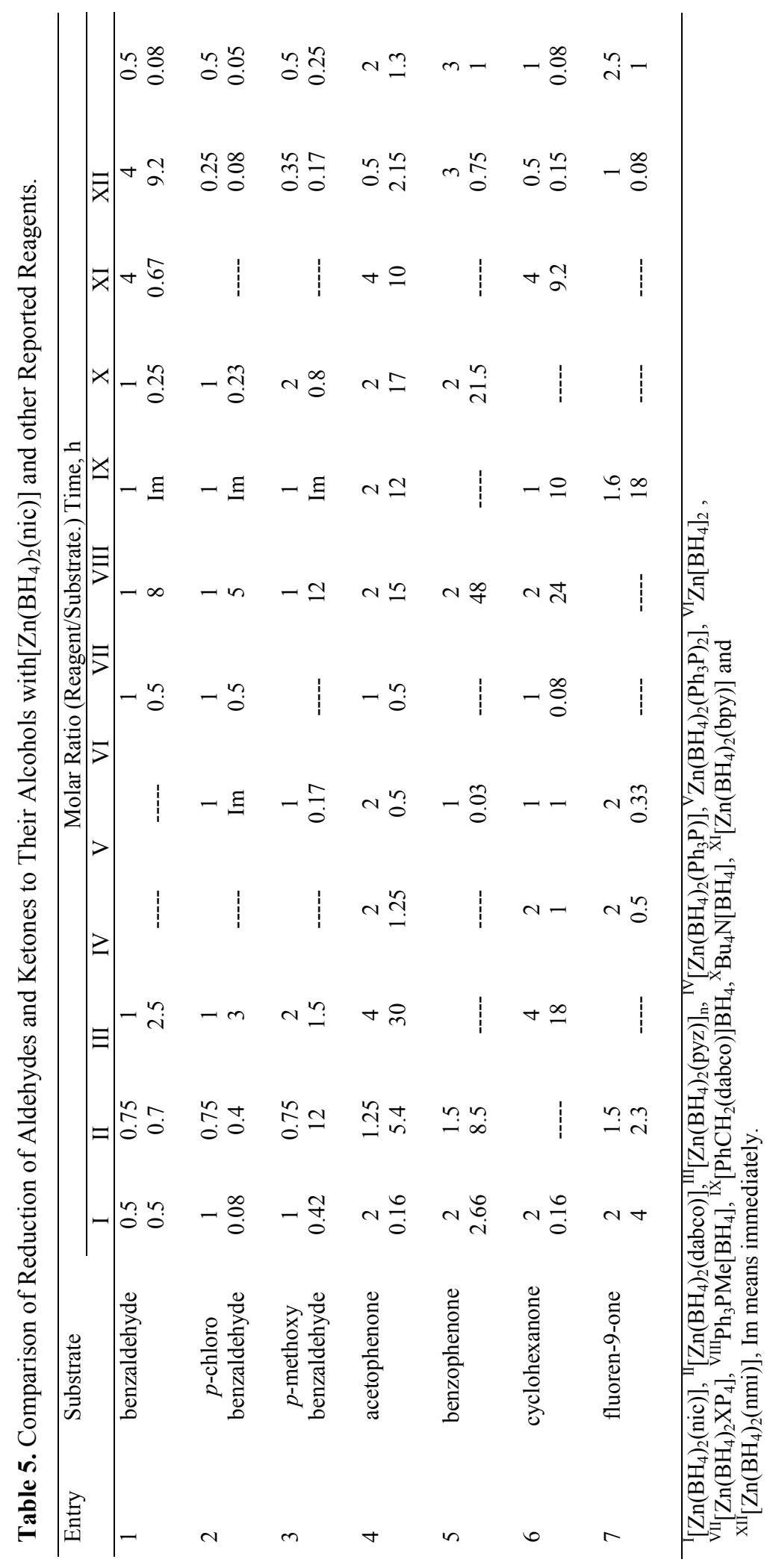




\section{Conclusion}

In this study, we prepared (Nicotine)(tetrahydroborato)zinc complex, $\left[\mathrm{Zn}\left(\mathrm{BH}_{4}\right)_{2}(\mathrm{nic})\right]$, as a new stable ligand-metal tetrahydroborate and utilized it as an efficient reducing agent. Preparation of this complex reagent is carried out simply and quantitatively by complexation of $\mathrm{Zn}\left(\mathrm{BH}_{4}\right)_{2}$ and nicotine at room temperature. Our observation shows that nicotine has a good ligand behavior for stabilizing of $\mathrm{Zn}\left(\mathrm{BH}_{4}\right)_{2}$ at room or higher temperature. Furthermore, the reducing ability of $\mathrm{Zn}\left(\mathrm{BH}_{4}\right)_{2}$ appears almost constant. $\left[\mathrm{Zn}\left(\mathrm{BH}_{4}\right)_{2}(\mathrm{nic})\right]$ appears a suitable reagent for the reduction of a variety of carbonyl compounds such as aldehydes, ketones, $\alpha$-diketones and acyloins to their corresponding alcohols at room temperature. The reduction reaction with $\left[\mathrm{Zn}\left(\mathrm{BH}_{4}\right)_{2}(\mathrm{nic})\right]$ in most cases was very efficient. Easy work-up procedure as well as the previous advantages makes this new modified tetrahydroborate agent as an attractive practical bench-top reagent and a synthetically useful metal tetrahydroborate complex.

Table 6. Reduction of acyloins and $\alpha$-diketones with $\left[\mathrm{Zn}\left(\mathrm{BH}_{4}\right)_{2}(\mathrm{nic})\right]$ at Room Temperature in $\mathrm{CH}_{3} \mathrm{CN}$.

\begin{tabular}{|c|c|c|c|c|c|}
\hline Entry & Substrate & Product & $\begin{array}{c}\text { Molar ratio } \\
\text { Reagent/Substrate }\end{array}$ & $\begin{array}{l}\text { Time, } \\
\text { min }\end{array}$ & $\begin{array}{l}\text { Yield }{ }^{\mathrm{a}}, \\
\%\end{array}$ \\
\hline 1 & benzil & $\begin{array}{c}\text { 1,2-diphenyl ethane- } \\
\text { 1,2-diol }\end{array}$ & $2: 1$ & 40 & 95 \\
\hline 2 & benzoin & $\begin{array}{l}\text { 1,2-diphenyl ethane- } \\
\text { 1,2-diol }\end{array}$ & $2: 1$ & 30 & 93 \\
\hline 3 & $\begin{array}{l}\text { 1,2-bis(4-methoxyphenyl) } \\
\text { ethane-1,2-dione }\end{array}$ & $\begin{array}{c}\text { 1,2-bis(4- } \\
\text { ethoxyphenyl) ethane- } \\
1,2 \text {-diol }\end{array}$ & $2: 1$ & 40 & 92 \\
\hline 4 & $\begin{array}{l}\text { 2-hydroxy-1,2-bis(4- } \\
\text { methoxyphenyl) ethanone }\end{array}$ & $\begin{array}{c}\text { 1,2-diphenyl ethane- } \\
\text { 1,2-diol }\end{array}$ & $2: 1$ & 40 & 94 \\
\hline 5 & $\begin{array}{l}\text { 1,3-diphenyl propane-1,2- } \\
\text { dione }\end{array}$ & $\begin{array}{l}\text { 1,3-diphenyl propane- } \\
\text { 1,2-diol }\end{array}$ & $2: 1$ & 50 & 88 \\
\hline
\end{tabular}

${ }^{\mathrm{a}}$ Yields refer to isolated pure products.

\section{Acknowledgment}

The authors gratefully appreciated the financial support of this, work by the research council of Islamic Azad University branch of Mahabad. The assistance of Mr. Avat Ali Poramjad for running FT-IR spectra and ${ }^{1} \mathrm{H}$ NMR spectra is also acknowledged.

\section{References}

1. (a) House H O, In Modern Synthetic Reaction, Benjamine, Menlo Park, CA, 1972. (b) Burk S D and Danheiser R L, Handbook of Reagents for Organic Synthesis, Oxidising and Reducing Agents; Wiley-VCH: New York, 1999. (c) Seyden-Penne J, Reductions by the Alumino and Borohydrides in Organic Synthesis; Wiley-VCH: New York, 1997. (d) Hudlicky M, Reductions in Organic Chemistry; Ellis Horwood: Chichester, 1984.

2. a) Brown H C, Narasimhan S, Choi Y M J. Org. Chem. 1982, 47, 4702. b) Oai K, Ookawa A J. Org. Chem.1986, 51, 4000. c) Arase A, Nunokawa Y, Masuda Y, Hoshi Y M J. Chem. Soc. Chem. Commun. 1991, 205.

3. Nishiwaki I, Fujiyama F Synthesis 1972, 569. 
4. Fujii H, Oshima K, Utimoto K Chem. Lett. 1991, 1847.

5. a) Osborn M E, Pegues, J F, Paquett, L A J. Org. Chem. 1980, 45, 167.

b) G. Fleet W J, Harding P J C Tetrahedron Lett. 1981, 22, 675. c) Cowan J A Tetrahedron Lett. 1986, 27, 1205.

6. a) Gensler W J, Johnson F, Sloan A D B J. Am. Chem. Soc. 1960, 82, 6074. b) Crabbe P G, Garcia A, Rius C J. Chem. Soc., Perkin Trans. 1, 1973, 810.

7. a) Ravikumar K, Baskaran S S, Chandrasekaran S Tetrahedron Lett. 1993, 34, 171. b) Marks T J, Kolb J R Chem. Rev. 1977, 77, 263.

8. (a) Ranu, B C Synlett 1993, 885. (b) Narasimhan S, Balakumar A Aldrichimica Acta 1998, 31, 19.

9. (a) Kotsuki H, Ushio Y, Yoshimura N, Ochi M Bull. Chem. Soc. Jpn. 1988, 61, 2684. (b) Kotsuki H, Ushio Y, Yoshimura N, Ochi M J. Org. Chem. 1987, 52, 2594. (c) Ranu, B C, Das A R J. Chem. Soc. Perkin Trans. 1 1992, 1561.

10. Tamami B, Lakouraj M M Synth. Commun. 1995, 25, 3089.

11. Firouzabadi H, Adibi M, Zeynizadeh B Synth. Commun. 1998, 28, 1257.

12. a) Firouzabadi H, Adibi M, Ghadami M. Phosphorus, Sulfur, Silicon Relat. Elem. 1998, 142, 191. b) Zeynizadeh B Bull. Chem. Soc. Jpn. 2003, 76, 317. c) Zeynizadeh B, Setamdideh D Asian Journal of Chemistry 2009, 21, 3603.

13. (a) Ranu B C, Chakraborty R Tetrahedron Lett. 1990, 31, 7663. (b) Sarkar D C, Das A R, Ranu B C J. Org. Chem. 1990, 55, 5799.

14. Firouzabadi H, Tamami B, Goudarzian N Synth. Commun. 1991, 21, 2275.

15. (a) Firouzabadi H, Adibi M Synth. Commun. 1996, 26, 2429. (b) Firouzabadi H, Adibi M Phosphorus, Sulfur, Silicon Relat. Elem. 1998, 142, 125.

16. (a) Firouzabadi H, Afsharifar G R Synth. Commun. 1992, 22, 497. (b) Firouzabadi H, Afsharifar G R Bull. Chem. Soc. Jpn. 1995, 68, 2595.

17. Raber D J, Guida W C J. Org. Chem. 1976, 41, 690, 1976.

18. Pechmann V H, Dahl F Chem. Ber. 1890, 23, 2421.

19. Ho T L, Olah G A, Synthesis 1976, 815.

20. Mori T, Nakahara T, Nozaki H Can. J. Chem. 1969, 47, 3266.

21. Mayer R, Hiller G, Nitzschke M, Jentzsch J Angew. Chem. 1963, 75, 1011.

22. Rubin M B, Ben-Bassat J M Tetrahedron Lett. 1971, 12, 3403.

23. Blomquist A T, Goldstein A Org. Syn. 1963, Coll. Vol. 4, 216.

24. Guette J P, Spassky N, Boucherot D Bull. Chem. Soc. Fr. 1972, 11, 4217. 


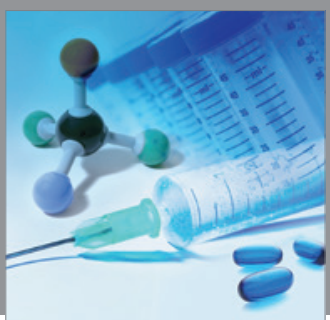

International Journal of

Medicinal Chemistry

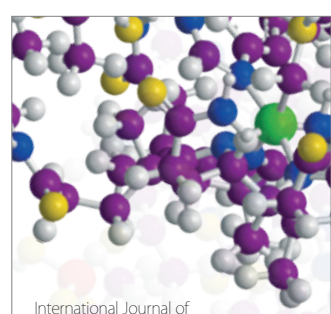

Carbohydrate Chemistry

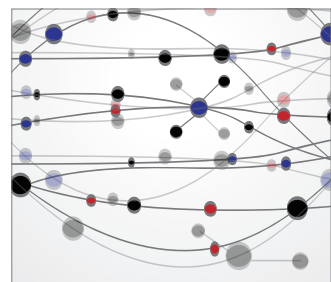

The Scientific World Journal
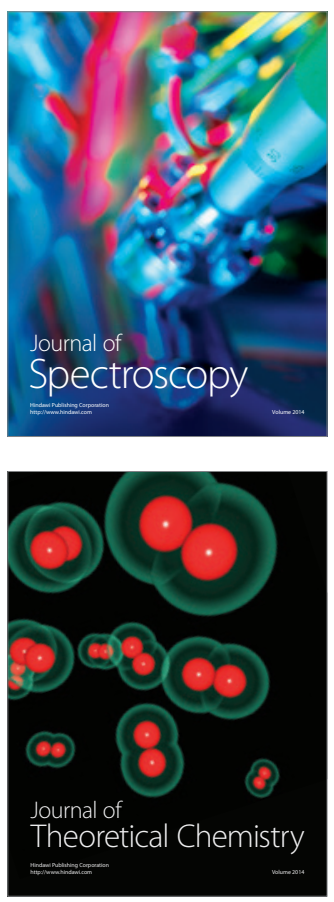
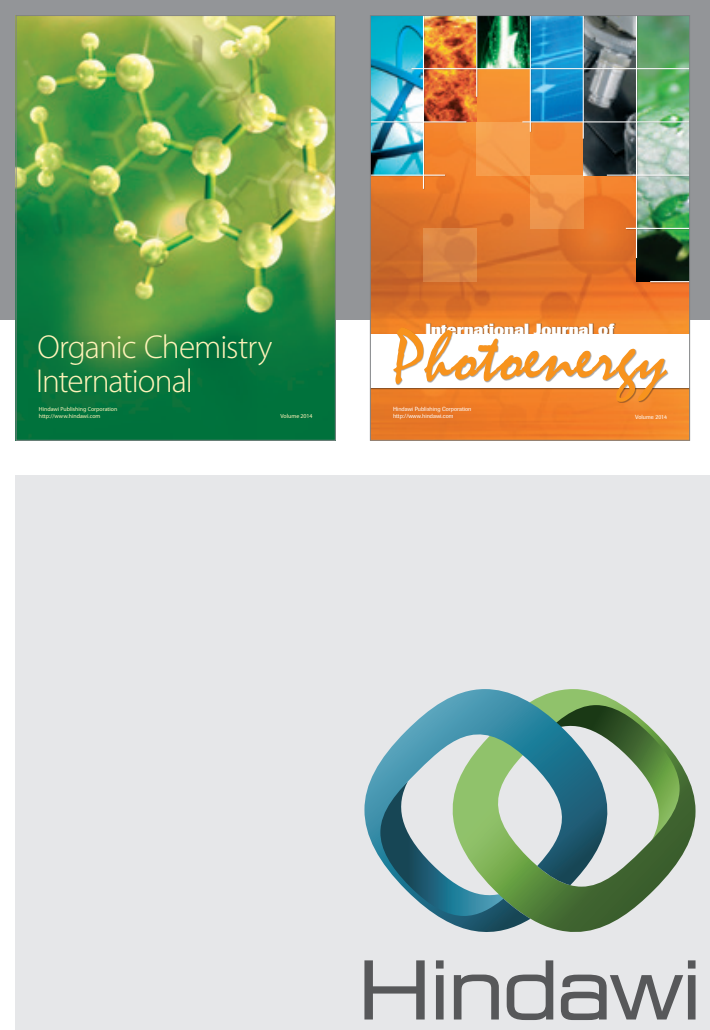

Submit your manuscripts at

http://www.hindawi.com
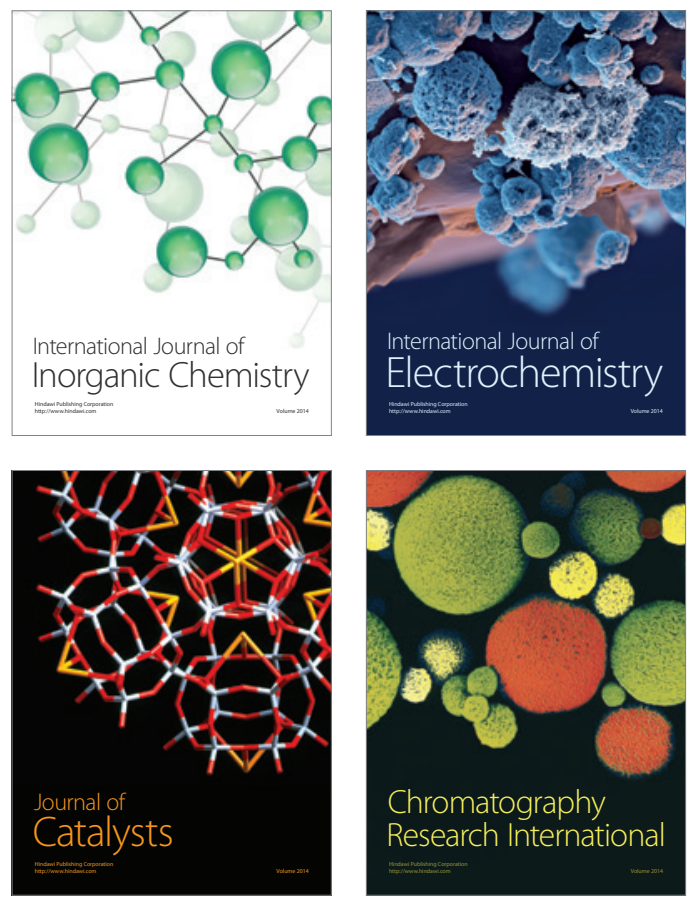
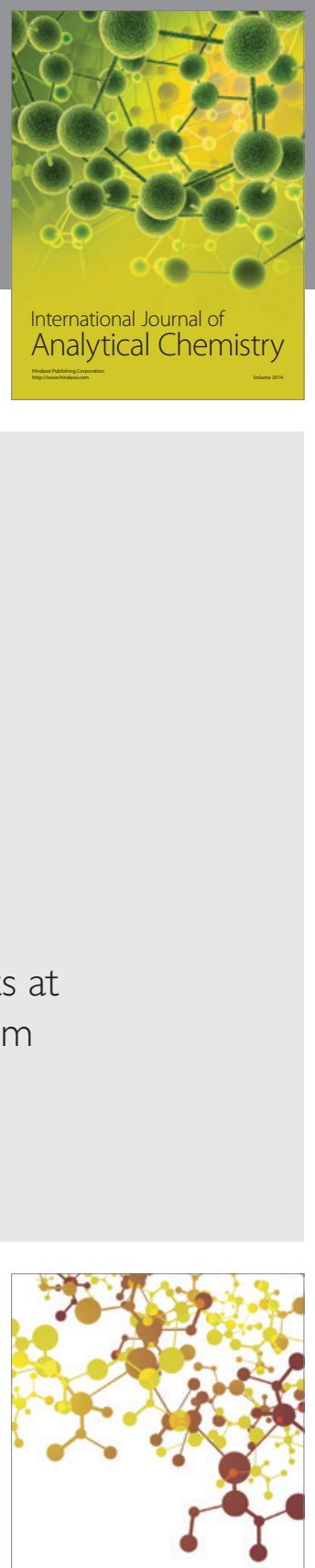

Journal of

Applied Chemistry
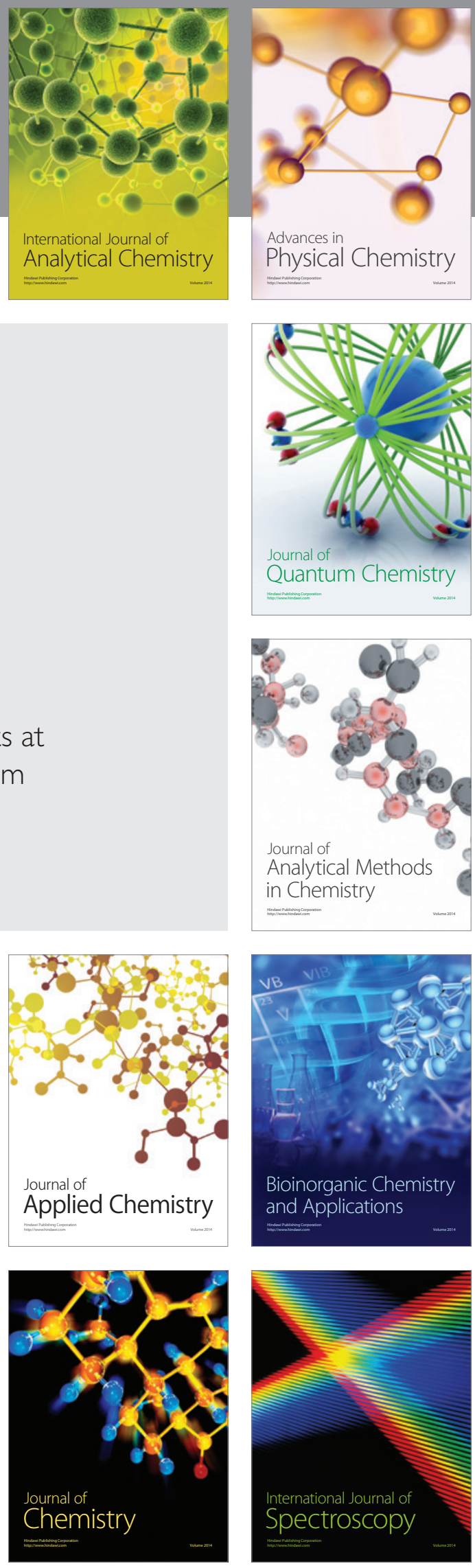